\title{
Taxonomic Study of the Genus Campylobacter Sebald and Véron and Designation of the Neotype Strain for the Type Species, Campylobacter fetus (Smith and Taylor) Sebald and Véron
}

\author{
M. VÉRON ${ }^{1}$ and R. CHATELAIN \\ Faculté de Médecine Necker et Institut Pasteur, Paris, France
}

\begin{abstract}
A critical study of the present state of the classification of vibrio-like, curved, microaerophilic bacteria was made. The species originally described under the names Vibrio coli Doyle, $V$. jejuni Jones et al., $V$. sputorum Prévot, and $V$. bubulus Florent are transferred to the genus Campylobacter Sebald and Véron 1963. The authors suggest that the type species of this genus, C. fetus, be divided into two subspecies: $C$. fetus subsp. fetus (Smith and Taylor) comb. nov. (syn. V. fetus subsp. intestinalis Florent), which contains the neotype strain of the species, and $C$. fetus subsp. venerealis (Florent) comb. nov. The previously described subspecies $V$. fetus subsp. intermedius Elazhari is regarded as an infrasubspecific taxon with the name $C$. fetus subsp. venerealis biotype intermedius. CIP $5396(=$ ATCC $27374=$ NCTC 10842) is proposed as the neotype strain of $C$. fetus subsp. fetus. This strain, then, is also the neotype strain of $C$. fetus (Smith and Taylor) Sebald and Véron.
\end{abstract}

In 1913, McFadyean and Stockman (34) discovered a "vibrio" which seemed to be responsible for abortion of pregnant ewes; they obtained an experimental abortion in pregnant cows by inoculation with this organism. Subsequently, Smith (52) recovered a microaerophilic "spirillum" from aborted calves. Smith (52) suspected that this organism was identical to that described by McFadyean and Stockman (34). It was designated Vibrio fetus by Smith and Taylor (53), the generic attribution being based on the fact that comma-shaped cells predominate over spirilloid ones, particularly in young cultures.

Nevertheless, assignment of this organism to the genus Vibrio is unsatisfactory: $V$. fetus differs greatly in phenotypic respects from the type species of the genus Vibrio, V. cholerae Pacini $1854(14,24,55)$. Moreover, the G + C content of the deoxyribonucleic acid (DNA) of $V$. fetus is very far from that characteristic of $V$. cholerae and related Vibrio species $(47,55)$.

${ }^{1}$ Laboratoire de Bactériologie, Faculté de Médecine Necker, 156, rue de Vaugirard, 75730, Paris Cedex 15, France.
The only shared property-curved cells-is now recognized to be a characteristic of dubious taxonomic value (10).

For these reasons, Sebald and Véron (47) proposed a new genus, Campylobacter, with $C$. fetus (Smith and Taylor) Sebald and Véron as the type species. The genus Campylobacter is defined $(47,54)$ as comprising gram-negative, slender, and curved bacteria which are motile by means of a single, polar flagellum, microaerophilic with a strictly respiratory metabolism, produce no acid in media with carbohydrates, and which have DNA with a $\mathrm{G}+\mathrm{C}$ content between 29 and $36 \mathrm{~mol} \%$. The genus Vibrio, on the other hand, comprises bacteria which ferment glucose $(24,25,54)$ and contain DNA with a $\mathrm{G}+\mathrm{C}$ content between 40 and $53 \%$, (J. M. Shewan and M. Véron, Bergey's Manual, 8 th ed., in press), the value for $V$. cholerae being about $47 \mathrm{~mol} \%$ (54).

Though the taxonomic notion of the family among the bacteria is difficult, or even impossible, to justify by means of genetic arguments, this taxon is useful for purposes of classification. Thus we have proposed $(54,55)$ to 
include the genus Campylobacter in the family Spirillaceae because there is much morphological and physiological likeness between the genera Campylobacter and Spirillum. In agreement with this view, striking analogies were observed $(13,45)$ between the anatomical features of strains belonging to both of these genera, particularly on account of the presence of: (i) an outer wavy membrane, or "integument," easily separated from the inner membrane with a large vacant space between both membranes; (ii) a "complex cytoplasmic membrane" consisting of a triple-layered membrane associated with short bar-like elaborations making up centripetally oriented compartments; and (iii) individual flagellar basal granules.

Since Smith and Taylor's description of $V$. fetus (53), there have appeared descriptions of several other species or subspecies of microaerophilic curved bacteria which should also be included in the genus Campylobacter. These taxa are the following:

(i) Vibrio fetus subsp. intestinalis Florent 1959 (20, p. 7), the strains of which occur principally in the intestinal tracts of sheep, cattle, swine, birds, and humans, where it is usually commensal. It has also been isolated occasionally from the genital tract, the viscera, or the blood. All strains can cause sporadic abortion (principally in cows and sheep) $(1,20)$ because they are able to multiply in the placenta after passage from the intestine into the viscera. Human infection is very often due to this subspecies. Some strains are able to be transferred by venereal contact and to survive in genital tracts of cattle $(13,21,39)$.

(ii) $V$. fetus subsp. venerealis Florent 1959 $(20$, p. 7$)$ seems strictly adapted to the bovine genital tract (preputial and vaginal cavities) and is unable to survive in the intestinal tract (8). It causes enzootic venereal sterility in cows (49) and, contingently, abortion in pregnant cows (20).

(iii) V. fetus subsp. intermedius Elazhary $1968(13$, p. 17), first described by Florent (21, p. 1072) as "intermediate group," is adapted in cattle to the genital tract as well as to the intestines (21). Strains of this subspecies could be transferred by venereal processes (39).

(iv) $V$. coli Doyle $1948(11$, p. 51) is a normal inhabitant of the intestines of swine, poultry, and (occasionally) man, but it is absent in sheep and cattle (13). It can cause dysentery in swine, hepatitis in birds, and bloody diarrhoea in man.

(v) V. jejuni Jones et al. 1931 (26, p. 861) frequently occurs in the intestinal tracts of cattle and sheep (13), in which it can cause mild dysentery.

(vi) V. sputorum Prévot 1940 (43, p. 123) and $V$. bubulus Florent 1953 (18, p. 2066) have very similar characteristics; their consolidation as two separate subspecies in a single species, as proposed by Loesche et al. (33), appears desirable. On the basis of priority, the specific epithet to be used in the name of the species is sputorum. V. sputorum subsp. sputorum Prévot is an occasionally pathogenic human parasite (33, p. 1109); it has been principally recovered from the oral cavity in gingivitis or from sputum in bronchitis. $V$. sputorum subsp. bubulus (Florent) Loesche et al. $1965(33$, p. 1109) appears to be nonpathogenic; it has been isolated from vaginal and preputial secretions, sperm, fetuses, and fetal membranes, and from stools of sheep, horses, and cattle.

At times, another species, Vibrio metschnikovii Gamaleia 1888 (23, p. 485), has been improperly included in this group of bacteria because it was recovered from the intestinal tract of poultry suffering from dysentery. In fact, the reference strains of this species possess a $\mathrm{G}+\mathrm{C}$ content of DNA of about $46 \mathrm{~mol} \%$ (47) and a fermentative metabolism of glucose like that of $V$. cholerae (55). Consequently, this species belongs to the genus Vibrio and not to the genus Campylobacter.

Finally, the genus Campylobacter, at present, appears to comprise four species: C. fetus (Smith and Taylor) Sebald and Véron 1963 $(47$, p. 907$)$, which contains several subspecies, C. coli (Doyle) comb. nov., $C$. jejuni (Jones et al.) comb. nov., C. sputorum subsp. sputorum (Prévot) comb. nov., and $C$. sputorum subsp. bubulus (Florent) comb. nov. The inclusion of these last subspecies in the genus Campylobacter was previously suggested by Loesche et al. (33).

In the course of our work on this genus, we examined the properties of 40 Campylobacter strains, and we shall describe here the characteristics that permit the recognition or differentiation of species and subspecies.

When they proposed the creation of the genus Campylobacter, Sebald and Véron (47) selected $C$. fetus (Smith and Taylor) Sebald and Véron as the type species, but failed to indicate a type strain. No type strain was proposed by Smith and Taylor (53), who originally described the species, and none of their strains is now in culture. We have therefore selected a neotype strain, the characteristics of which are in full conformity with the rather fragmentary original description of the species (53) and of which a complete description follows. 


\section{MATERIALS AND METHODS}

Bacterial strains. Forty strains of Campylobacter species were examined, the designations and origins of which are indicated in Table 1. Strain CIP (Collection of the Pasteur Institute, Paris) 5396 was isolated in 1952 by Doctor Vinzent (Le Havre), who referred to it as "souche mouton 1." It was found in the brain of a sheep fetus belonging to a flock in which repeated abortions occurred; this enzootic was described by Vinzent and Alloy (56). This strain appears to be the first found in France from cases of sporadic cattle abortion. Since its isolation it has been preserved freeze-dried in the Collection of the Pasteur Institute in Paris, and it appears to have remained stable upon subculture. It has been deposited in the American Type Culture Collection, Rockville, Maryland (ATCC 27374) and the National Collection of Type Cultures, London, England (NCTC 10842).

Cultivation procedures. Agar plates and slants were incubated in a gaseous atmosphere of $5 \% \mathrm{O}_{2}, 10 \%$ $\mathrm{CO}_{2}$, and $85 \% \mathrm{~N}_{2}$, as recommended by Kiggins and Plastridge (27). All liquid and semi-solid media were incubated in air. Except where otherwise stated, the incubation temperature was $37 \mathrm{C}$.

Media used. (i) Nutrient agar: Lab Lemco beef extract (Oxoid Ltd., London), $5 \mathrm{~g}$; bacteriological peptone $\mathrm{N}^{\mathrm{O}} 2$ (Industrie Biologique Française, 92Gennevilliers, France), $10 \mathrm{~g} ; \mathrm{NaCl}, 5 \mathrm{~g}$; Oxoid agar $\mathrm{N}^{\circ}$ $3,12 \mathrm{~g}$; water, $1,000 \mathrm{ml}$; $\mathrm{pH} 7.5$.

(ii) Blood agar: nutrient agar with $10 \%$ defibrinated horse blood.

(iii) Thiol agar: thiol broth (Difco Laboratories Inc., Detroit, Mich.) with $1.2 \%$ Oxoid agar $\mathrm{N}^{\circ} 3$.

(iv) Yeast extract agar: Difco yeast extract, $7 \mathrm{~g}$; $\mathrm{NaCl}, 5 \mathrm{~g}$; Oxoid agar $\mathrm{N}^{\circ} 3,12 \mathrm{~g}$; water, $1,000 \mathrm{ml}$.

(v) Deep nutrient gelatin agar (or "gélose-gélatine" of Legroux; formula quoted in reference 38): semisolid nutrient gelatin agar with glucose $(1 \%)$ and $\mathrm{KNO}_{3}$ $(0.05 \%)$, dispensed in $15-\mathrm{ml}$ amounts in test tubes $(16$ by $160 \mathrm{~mm}$ ), sterilized by autoclaving, and inoculated through the mass, after melting and cooling at $45 \mathrm{C}$.

(vi) Fluid Albimi broth: brucella broth (Albimi Laboratories, Flushing, N. Y.) with $0.12 \%$ Oxoid agar $\mathrm{N}^{\mathrm{O}} 3$.

(vii) Defined medium of Fletcher and Plastridge (17): L-aspartic acid, $2 \mathrm{~g}$; L-cysteine, $0.5 \mathrm{~g}$; L-glutamic acid, $3 \mathrm{~g}$; sodium ace tate, $5 \mathrm{~g} ; \mathrm{MgCl}_{2} \cdot 6 \mathrm{H}_{2} \mathrm{O}, 1 \mathrm{~g} ; \mathrm{NaCl}$, $5 \mathrm{~g} ; \mathrm{K}_{2} \mathrm{HPO}_{4}, 0.05 \mathrm{~g}$; nicotinic acid, $0.1 \mathrm{mg}$; Oxoid agar $\mathrm{N}^{\circ} 3,12 \mathrm{~g}$; demineralized water, $1,000 \mathrm{ml}$.

Assessment of relative growth rate on different media and at different temperature. For a comparative study of growth on a defined medium and on complex media, the method of Fletcher and Plastridge (17) was employed for CIP 5396. The complex media used were nutrient agar, blood agar, thiol agar, and yeast extract agar. The defined medium was that of Fletcher and Plastridge.

Each medium was dispensed in 7-ml amounts in test tubes (16 by $160 \mathrm{~mm}$ ), autoclaved at $115 \mathrm{C}$, and solidified in the same slanted position so that they each had the same surface area. Each slant was inoculated with $0.05 \mathrm{ml}$ of a saline $(0.85 \% \mathrm{NaCl})$ suspension containing approximately $10^{8}$ cells $/ \mathrm{ml}$. The cultures were incubated for 3 days, whereupon the cells from each medium were suspended in $8 \mathrm{ml}$ of $0.3 \%$ formalinized saline. The optical density (OD) was determined in a Meunier photometer at $550 \mathrm{~nm}$.

A comparison of growth was made in different atmospheres (air; $10 \% \mathrm{CO}_{2}$ in air; $5 \% \mathrm{O}_{2}$, plus $10 \%$ $\mathrm{CO}_{2}$, in nitrogen) and at various temperatures $(25,37$, and $45 \mathrm{C}$ ) in fluid Albimi broth.

Microscope investigations. The cells were examined after $40 \mathrm{~h}$ of growth on blood agar and nutrient agar. Motility was determined in hanging-drop preparations, and flagella were stained by Rhodes' method (44). CIP 5396 was examined in the electron microscope by metallic shadowing with palladium.

Biochemical tests. The production of catalase was determined by a slide test with $3 \% \mathrm{H}_{2} \mathrm{O}_{2}$, and the production of oxidase with Kovacs' method (30) using $1 \%$ para-amino-dimethyl-aniline oxalate as reagent. To detect nitrate reductase, a fluid Albimi broth supplemented with $0.1 \% \mathrm{KNO}_{3}$ was inoculated and incubated for $48 \mathrm{~h}$, and then was tested for the presence of nitrites. The effect of chlorate on anaerobic growth was investigated by the method of Pichinoty and Piéchaud (41). Ability to produce $\mathrm{H}_{2} \mathrm{~S}$ was determined according to the method of Florent (20), as modified by Elazhary (13), by suspending a lead acetate paper strip set above two different media, either a "standard medium" which was a fluid Albimi broth or a "sensitive medium" consisting of the same medium supplemented with $0.02 \%$ cystine- $\mathrm{HCl}$; reading of blackening of paper was done after 4 and 6 days. The effect of the bacteria on glucose was detected in the medium of Hugh and Leifson (25) after 2, 4, and 8 days. Gelatin hydrolysis (22) was determined after 4 days, and the production of indole after 2 and 4 days in peptone water (1\% bacteriological peptone IBF $\mathrm{N}^{\circ} 2$ ) containing $0.5 \% \mathrm{NaCl}$.

Tests of tolerance. Glycine tolerance (32) was determined according to Florent's technique (20) in fluid Albimi broth containing $1 \%$ glycine, and readings were made after 6 days. The effects of bile (46), $\mathrm{NaCl}$ (31), and glucose (31) on growth were tested for after 6 days in fluid Albimi broth supplemented with 1 or $10 \%$ ox bile, $3.5 \% \mathrm{NaCl}$, or $8 \%$ glucose, respectively. Tolerance towards and reduction of sodium selenite (5) was determined after 6 days on brucella agar (Albimi) with $0.1 \%$ sodium selenite. The ability to grow on Brilliant Green agar was estimated by a modification of the technique of Florent (19), using a blood agar supplemented with $1 / 33,000$ Brilliant Green (Difco), and read after 3 days. Tolerance towards nalidixic acid and towards 2,3,5-triphenyltetrazolium chloride (TTC) (Thibault and Florent, personal communication) was determined by the ability to grow after 3 days on blood agar containing either $40 \mu \mathrm{g}$ of nalidixic acid per $\mathrm{ml}$ or $1 \mathrm{mg}$ of TTC per $\mathrm{ml}$. The test of Shewan et al. (48) was performed on blood agar with disks impregnated by an acetone solution of $1 \%$ vibriostatic compound $0 / 129(2,4-\mathrm{di}$ amino-6,7-di-isopropylpteridine) and was read for growth after 3 days.

$\mathbf{G}+\mathbf{C}$ content of DNA. In this study, as in a previous work (47), the extraction of bacterial DNA was done by the method of Bøvre and Henriksen (4). The ribonucleic acid (RNA) was hydrolyzed overnight in $1 \mathrm{~N} \mathrm{NaOH}$ at $37 \mathrm{C}$, after which the DNA was 
TABLE 1. Designations and origins of the 40 strains of Campylobacter examined ${ }^{a}$

\begin{tabular}{|c|c|c|c|}
\hline $\begin{array}{c}\text { Reference in } \\
\text { CIP }\end{array}$ & Supplied by & $\begin{array}{c}\text { Strain } \\
\text { designation }\end{array}$ & Source \\
\hline \multicolumn{4}{|l|}{$\begin{array}{l}\text { C. fetus subsp. } \\
\text { fetus }\end{array}$} \\
\hline A168 & J. G. & Leg. & Human blood \\
\hline A169 & R. V. & Mar. & Human blood \\
\hline 5392 & R. V. & VB & Animal \\
\hline 5393 & A. F. & 661 & Sheep \\
\hline 5395 & Curator of NCTC & NCTC 5850 & Sheep, contagious abortion \\
\hline 5396 & R.V. & Mouton 1 & Sheep fetus \\
\hline 5411 & P. T. & R. Br. & Human blood \\
\hline 5515 & P. T. & Gal. & Human blood \\
\hline 571 & P. T. & Lix. & Human blood \\
\hline 5721 & P. T. & Via. & Human blood \\
\hline 5867 & P. T. & Leb. & Human blood \\
\hline 688 & A. F. & 7572 & Bull prepuce \\
\hline 6823 & W. W. & $\mathrm{Pb} 819$ & Unknown \\
\hline 6824 & W. W. & $\mathrm{Ab} 71$ & Unknown \\
\hline 6943 & A. F. & 922 & Bull prepuce \\
\hline 6944 & A. F. & $2137 / 2$ & Bull prepuce \\
\hline 7084 & P. T. & Dur. & Human blood \\
\hline 7085 & P. T. & Tho. & Human blood \\
\hline \multirow{2}{*}{\multicolumn{4}{|c|}{$\begin{array}{l}\text { C. fetus subsp. } \\
\text { venerealis }\end{array}$}} \\
\hline & & & \\
\hline 53105 & A. F. & 483 & Cow \\
\hline 5419 & A. F. & 995 & Cow \\
\hline 5427 & A. F. & $\mathrm{S}$ & Cow \\
\hline 6822 & W. W. & $\mathrm{Pb} 1225$ & Unknown \\
\hline 6829 & Curator of NCTC & NCTC 10354 & Vaginal mucus of heifer \\
\hline 6945 & A. F. & 16977 & Bull prepuce \\
\hline \multicolumn{4}{|l|}{ C. fetus subsp. } \\
\hline venerealis & & & \\
\hline $\begin{array}{l}\text { biotype } \\
\text { intermedius }\end{array}$ & & & \\
\hline 5399 & R. V. & Ville. & Human blood \\
\hline 5443 & E. O. & 1134 & Human blood \\
\hline \multicolumn{4}{|l|}{ C. coli } \\
\hline 6825 & W. W. & A4 & Unknown \\
\hline 7054 & A. F. & 3949 & Pig feces \\
\hline 7077 & A. F. & P2 & Pig feces \\
\hline 7078 & A. F. & P3 & Pig feces \\
\hline 7079 & A. F. & P6 & Pig feces \\
\hline 7080 & A. F. & 1407 & Pig feces \\
\hline 7081 & A. F. & P9 & Pig feces \\
\hline 7086 & P. T. & Tan. & Human blood \\
\hline 715 & A. F. & P875 & Pig feces. \\
\hline \multicolumn{4}{|l|}{ C. jejuni } \\
\hline 702 & A. F. & $\begin{array}{l}\text { Uccle } \\
91 \text { F.B. }\end{array}$ & Bovine feces \\
\hline \multicolumn{4}{|l|}{$\begin{array}{l}\text { C. sputorum } \\
\text { subsp. } \\
\text { bubulus }\end{array}$} \\
\hline 53103 & A. F. & Wat. & Bull sperm \\
\hline 5420 & A. F. & Ato. & Bull sperm \\
\hline 5421 & A. F. & Imp. & Bull sperm \\
\hline 5422 & A. F. & Mix. & Bull sperm \\
\hline
\end{tabular}

${ }^{a}$ Abbreviations: CIP, Collection of Pasteur Institute, Paris, France; NCTC, National Collection of Type Cultures, London, England. J. G., J. Gaillard, Paris, France; R. V., R. Vinzent, Le Havre, France; A. F., A. Florent, Bruxelles, Belgium; P. T., P. Thibault, Paris, France; W. W., W. Winkenwerder, Hanover, Germany; E. O., E. O. King, Atlanta, Georgia, U.S.A. 
hydrolyzed with $12 \mathrm{~N} \mathrm{HClO}_{4}$ at $100 \mathrm{C}$ for $1 \mathrm{~h}$. The free bases were separated by paper chromatography by Wyatt's method (57) by using a mixture of isopropanol-HCl-water $(68: 18: 14$, vol $/ \mathrm{vol} / \mathrm{vol})$. The four bases were eluted in $0.1 \mathrm{~N} \mathrm{HCl}$ and measured with a Beckman DB spectrophotometer. The results are expressed as moles percent of guanine + cytosine in the DNA.

Serological typing. Typing was performed by tube agglutination using heated bacterial suspensions and dilutions at 1/20 or higher of $0: 1$ and $0: 2$ antisera. The bacterial suspensions for agglutination reactions and immunizations were prepared from smooth cultures incubated for $40 \mathrm{~h}$ on the surface of nutrient agar; the cells were suspended in $0.3 \%$ formalinized saline, then heated at $100 \mathrm{C}$ for $2 \mathrm{~h}$, and diluted to provide an optical density of 0.31 at $550 \mathrm{~nm}$. Antisera were prepared in rabbits, using strains $\mathrm{Pb} 1225$ and $\mathrm{Pb}$ 819 of $C$. fetus received from W. Winkenwerder as immunizing antigens. These strains belong to serotypes $\mathrm{O}: 1$ and $\mathrm{O}: 2$, respectively, of Mitscherlich and Liess (35), which correspond to serotypes A and B, respectively, of Morgan (37) and Berg et al. (3).

\section{RESULTS}

Previous publications $(1,3,7,13,20,21,39$, $42,50)$ have revealed three basic criteria which permit specific differentiation of campylobacters. These are: production of catalase (6); growth in a medium containing glycine (32) at $1 \%$ concentration (20); and production of $\mathrm{H}_{2} \mathrm{~S}$ determined in the "standard medium" (13) described above. Our own experience, based on a study of more than 40 strains, has confirmed the usefulness of these three criteria, supplemented by certain other tests shown in Tables 2 and 3 , for the differentiation of species and subspecies of the genus Campylobacter. All strains studied here gave similar results for the tests reported in Tables 2 and 3.

The serotypes of 26 strains of $C$. fetus were determined with $0: 1$ and $0: 2$ antisera. For $V$. fetus subsp. venerealis, 3 strains belonged to serotype 0:1, and 1 strain (CIP 6829) was not agglutinable. Both strains of $V$. fetus subsp. intermedius also belonged to serotype $0: 1$. For $V$. fetus subsp. intestinalis, 5 strains belonged to serotype $0: 1,8$ strains to serotype $0: 2$, and 1 strain (CIP 5721) was not agglutinable. Determinations of the heat-stable serotypes of the strains of $V$. coli, $V$. jejuni, and $V$. sputorum subsp. bubulus were not made.

Strain CIP 5396, designated as the neotype of C. fetus, is described below. Strains CIP 7080, CIP 702, and CIP 53103 are proposed, respectively, as reference strains for $C$. coli, $C$. jejuni, and C. sputorum subsp. bubulus.

\section{DISCUSSION}

On the basis of the results presented here and those previously published, Campylobacter strains can be grouped as follows:
1. Strains catalase positive and $\mathrm{H}_{2} \mathrm{~S}$ negative. These strains, which are moderately microaerophilic, constitute the type species, Campylobacter fetus (Smith and Taylor) Sebald and Véron. This species can be split into three subspecies (or varieties) on cultural, biochemical, and ecological grounds; it can also be divided into several serotypes.

The clear differentiation of serotypes among strains of $C$. fetus was possible only after the demonstration of specificity of somatic heatstable antigens by means of agglutination tests $(3,13,37)$ as well as complement fixation tests $(13,35)$. According to the results of these studies, three main heat-stable serotypes, designated A, B, and C by Berg et al. (3), could be distinguished in $C$. fetus. Rare strains may simultaneously possess antigens $\mathrm{A}$ and $\mathrm{B}$, or $\mathrm{A}$, $B$, and $C(3)$.

The subspecies of $C$. fetus are as follows:

(a) C. fetus subsp. fetus (Smith and Taylor) comb. nov. (synonym: Vibrio fetus subsp. intestinalis Florent). This subspecies has a fairly fast growth rate, colonies being well developed after $48 \mathrm{~h}$. The chief features for the diagnosis of this subspecies are given in Table 2. C. fetus subsp. fetus corresponds to: group III strains of Akkermans et al. (1); some "related vibrios" of King $(28,29)$; ty pe II strains of Mohanty et al. (36); type 2 strains of Bryner et al. (7); group II organisms of Plastridge et al. (42); the majority of biotype 2 strains of Smibert (51); and organisms of groups A-2 and B of Berg et al. (3).

(b) C. fetus subsp. venerealis (Florent) comb. nov. (synonym: Vibrio fetus subsp. venerealis Florent). This subspecies grows somewhat more slowly than the preceding subspecies; the colonies are well developed only after three days. Growth is inhibited in a $1 \%$ glycine medium (see Table 2). This subspecies is probably identical to type I strains of Akkermans et al. (1), type I strains of Mohanty et al. (36), type 1 strains of Bryner et al. (7), type A strains of Park et al. (39), group I organisms of Plastridge et al. (42), biotype 1 strains of Smibert (51), and group A-1 strains of Berg et al. (3). The majority of strains in this subspecies belong to serotype A (3).

$V$. fetus subsp. intermedius Elazhary is very similar in its biochemical characteristics (Table 2) to $C$. fetus subsp. venerealis except that it produces $\mathrm{H}_{2} \mathrm{~S}$ in the "sensitive medium" described above. In a $1 \%$ glycine medium, growth does not occur or is very slow. Reduction of $0.1 \% \mathrm{Na}$ selenite is weak or absent. This subspecies corresponds closely to type III strains of Mohanty et al. (36), sub-type strains 1 of Bryner et al. (7), biotype $1 \mathrm{~A}$ strains 
TABLE 2. Differentiation of catalase-positive strains of Campylobacter

\begin{tabular}{|c|c|c|c|c|c|c|c|c|c|c|c|c|}
\hline \multirow[b]{2}{*}{$\begin{array}{l}\text { Species and } \\
\text { subspecies }\end{array}$} & \multirow[b]{2}{*}{$\begin{array}{l}\text { No. of } \\
\text { strains }\end{array}$} & \multicolumn{11}{|c|}{ Characteristics $^{a}$} \\
\hline & & BG1 & BG3 & GLY & GLU & NA & TTC & $25 \mathrm{C}$ & $42 \mathrm{C}$ & $\mathrm{SN}$ & $\mathrm{H}_{2} \mathrm{~S}$ & $\mathrm{H}_{2} \mathrm{~S}^{*}$ \\
\hline $\begin{array}{l}\text { C. fetus subsp. } \\
\text { fetus }\end{array}$ & 18 & + & + & + & + & + & - & + & - & + & - & + \\
\hline $\begin{array}{l}\text { C. fetus subsp. } \\
\text { venerealis }\end{array}$ & 6 & + & + & - & + & + & - & + & - & - & - & - \\
\hline $\begin{array}{l}\text { C. fetus subsp. } \\
\text { venerealis } \\
\text { biotype } \\
\text { intermedius }\end{array}$ & 2 & + & + & - & + & + & - & + & - & - & - & + \\
\hline C. coli & 9 & + & - & + & + & - & + & - & + & + & $\mathrm{d}$ & + \\
\hline C. jejuni & 1 & - & - & + & - & - & w & - & + & w & $\mathrm{w}$ & + \\
\hline
\end{tabular}

${ }^{a}$ Abbreviations and symbols: BG1, growth in Brilliant Green 1/100,000; BG3, growth in Brilliant Green $1 / 33,000 ; \mathrm{GLY}$, growth in $1 \%$ glycine; GLU, growth in $8 \%$ glucose; NA, growth in $40 \mu \mathrm{g}$ of nalidixic acid per ml; TTC, growth in $1 \mathrm{mg}$ of 2,3,5-triphenyltetrazolium chloride per ml; $25 \mathrm{C}$, growth at $25 \mathrm{C} ; 42 \mathrm{C}$, growth at $42 \mathrm{C}$; $\mathrm{SN}$, reduction of $\mathrm{Na}$ selenite; $\mathrm{H}_{2} \mathrm{~S}$, production of $\mathrm{H}_{2} \mathrm{~S}$ in "standard medium;" $\mathrm{H}_{2} \mathrm{~S}$, production of $\mathrm{H}_{2} \mathrm{~S}$ in "sensitive medium;" -, no growth or negative reaction; $w$, weakly positive reaction; +, growth or positive reaction; $d$, various results.

TABLE 3. Differentiation of catalase-negative strains of Campylobacter

\begin{tabular}{l|c|c|c|c|c|c|c|c}
\hline & & \multicolumn{7}{|c|}{ Characteristics $^{\alpha}$} \\
\cline { 2 - 8 } $\begin{array}{c}\text { Species and } \\
\text { subspecies }\end{array}$ & $\begin{array}{c}\text { No. of } \\
\text { strains }\end{array}$ & CAT & $\mathrm{H}_{2} \mathrm{~S}$ & $\mathrm{GLY}$ & $\mathrm{Bile}$ & $\mathrm{NaCl}$ & $45 \mathrm{C}$ & $\mathrm{CO}_{2}$ \\
\hline $\begin{array}{c}\text { C. sputorum } \\
\text { subsp. sputorum }\end{array}$ & $0^{b}$ & - & + & $\mathrm{w}$ & + & - & - & - \\
$\begin{array}{c}C . \text { sputorum } \\
\text { subsp. bubulus } \\
\begin{array}{c}\text { Catalase-positive } \\
\text { strains }\end{array}\end{array}$ & 36 & - & + & + & - & + & - & - \\
\hline
\end{tabular}

a Abbreviations and symbols: CAT, production of catalase; $\mathrm{H}_{2} \mathrm{~S}$, production of $\mathrm{H}_{2} \mathrm{~S}$ in "standard medium;" GLY, growth in gly cine $1 \%$; Bile, growth in $1 \%$ ox bile; $\mathrm{NaCl}$, growth in $3.5 \% \mathrm{NaCl} ; 45 \mathrm{C}$, grow th at $45 \mathrm{C}$; $\mathrm{CO}_{2}$, growth in air with $10 \% \mathrm{CO}_{2} ;-$, no growth or negative reaction; + , growth or positive reaction; w, weak growth; d, various results.

${ }^{b}$ Characteristics cited from Loesche et al. (33).

of Smibert (51), and group A-sub 1 strains of Berg et al. (3). In general, these strains belong to serotype A (3).

2. Strains catalase positive and $\mathrm{H}_{2} \mathrm{~S}$ positive. These strains are characterized by an abundant production of $\mathrm{H}_{2} \mathrm{~S}$ in "sensitive media." The majority of them also produce copious $\mathrm{H}_{2} \mathrm{~S}$ in "standard media," that is to say in media in which a relatively insensitive method of detection is used (20). Two species are recognized:

(a) C. coli (Doyle) comb. nov. (synonym: Vibrio coli Doyle). This organism is the most aerotolerant and has the fastest growth rate of all the campylobacters, colonies usually appearing after $24 \mathrm{~h}$. According to our results, all strains reduce nitrates to nitrites; this characteristic is contrary to the original report of Doyle
(11) but is in agreement with more recent publications $(13,29)$. Furthermore, the reduction of nitrates to nitrites is a common property among the campylobacters. Of the characters that are of value for the differentiation of this species (see Table 2), two recently described by $P$. Thibault and A. Florent (personal communication) greatly facilitate recognition of this species: the absence of growth on blood agar containing $40 \mu \mathrm{g}$ of nalidixic acid per $\mathrm{ml}$; and good growth on blood agar containing $1 \mathrm{mg}$ of triphenyltetrazolium chloride per $\mathrm{ml}$ (TTC). Some strains from human sources described as "related vibrios" by King (28, 29), some chicken strains investigated by Peckham (40), and the strains of biotype 3 of Smibert (51) probably belong to this species. The last author (51) reports that the majority 
of $C$. coli strains (his biotype 3 ) are ribonuclease (RNase) or deoxyribonuclease (DNase) positive, or both, contrary to $C$. fetus strains (his biotypes 1 and 2). Elazhary (13) has demonstrated at least three specific $\mathrm{O}$ antigenic groups in this species.

(b) C. jejuni (Jones et al.) comb nov. (synonym: Vibrio jejuni Jones et al.). Classically, this is a rather rare and poorly defined organism. We have been able to examine only one strain of $C$. jejuni, a rather short, very motile, vibrio-shaped organism which is distinctly microaerophilic, very sensitive to Brilliant Green, does not grow in an $8 \%$ glucose medium, and weakly produces $\mathrm{H}_{2} \mathrm{~S}$ in the "sensitive medium." These characteristics are in agreement with the observations of Elazhary (13). According to Florent (personal communication), strains of $C$. jejuni do not grow in the nalidixic medium and irregularly grow in the presence of $1 \mathrm{mg}$ of TTC per ml. There are at least two specific $O$ antigenic groups in this species (13).

3. Catalase-negative strains. C. sputorum (Prévot) comb. nov. (synonym: Vibrio sputorum Prévot). This species is much less aerotolerant than the catalase-positive species, and it was originally considered to be a strict anaerobe. However, Loesche et al. (33) have shown that both subspecies of this species are microaerophilic and cannot grow without oxygen. The properties of our strains of $C$. sputorum subsp. bubulus (Florent) comb. nov. (synonym: vibrio bubulus Florent) are in full agreement with those of the strains described in the literature $(18,33)$. This subspecies agrees with type II strains of Akkermans et al. (1), type IV strains of Mohanty et al. (36), and group IV strains of Plastridge et al. (42).

The validity of including the four species cited above in the genus Campylobacter is supported by: (i) genetic data, as the average $G$ $+C$ contents of the DNA of these four species are $34.6,32.7,31.5$, and $30.1 \mathrm{~mol} \%$, respectively (see Table 4); and (ii) ultrastructure evidence, as the membrane structure of $C$. fetus described by Ritchie and Keeler (45) was also observed in $C$. coli and $C$. jejuni by Elazhary (13).

If the differentiation of C. fetus subsp. venerealis, C. sputorum subsp. sputorum (Prévot) comb. nov. (synonym: Vibrio sputorum subsp. sputorum Prévot), and C. sputorum subsp. bubulus presents no real difficulty, it is not the same for the campylobacters that are catalase positive and $\mathrm{H}_{2} \mathrm{~S}$ positive. These strains frequently are misidentified, which is easily understood because the principal character in their differentiation is the quantity of $\mathrm{H}_{2} \mathrm{~S}$ produced in more or less sensitive media.

It appears that the features used in differentiating $V$. fetus subsp. intermedius from the other two subspecies of $C$. fetus are not very numerous (see Table 2). Consequently, because $V$. fetus subsp. intermedius and C. fetus subsp. venerealis often have the same ecological niche, it is reasonable to consider the former as an $\mathrm{H}_{2}$ S-positive biotype (in a "sensitive medium") of the latter, the name of the latter having priority. Now, recognizing that a more extensive study is necessary to clarify the classification of the so-called $C$. jejuni group, the greatest taxonomic difficulty that remains with the campylobacters is differentiating between $V$. fetus subsp. intestinalis and C. coli.

A differentiation of these two taxa could actually be made on the basis of the following five characteristics showed by all of our strains of $C$. coli but not by strains of $V$. fetus subsp. intestinalis (see Table 2): (i) no growth occurs in the medium containing $40 \mu \mathrm{g}$ of nalidixic acid per ml; (ii) there is growth in blood agar containing $1 \mathrm{mg}$ of TTC per ml; (iii) growth is possible at $42 \mathrm{C}$; (iv) there is no growth at $25 \mathrm{C}$; and (v) cultures in fluid Albimi broth at $37 \mathrm{C}$ do not remain viable for more than 8 to 10 days. The temperature criteria for growth were proposed by King $(28,29)$ to differentiate her "related vibrio" from other V. fetus strains. On account of the last three characteristics, it is possible that the serotype $\mathrm{C}$ strains of Berg et al. (3), designated by them as Vibrio marshi, belong therefore to $C$. coli. In 1965, Firehammer (15) described under the name Vibrio faecalis strains that not only produced as much $\mathrm{H}_{2} \mathrm{~S}$ as $C$. sputorum subsp. bubulus but also produced catalase in abundance. We have not encountered strains of this sort, but it is not impossible that at least some strains identified as $V$. faecalis actually belong to $C$. coli.

The biochemical and ecological characteristics of $C$. fetus subsp. venerealis are so different from those of $V$. fetus subsp. intestinalis that these two subspecies should be maintained. However, recognition of these taxa as two distinct species cannot be justified because: (i) the $G+C$ contents of their DNA are similar (see Table 4); (ii) hybridizations up to $100 \%$ were obtained between the glycine-positive and glycine-negative biotypes of C. fetus (2); (iii) there is a close genetic relationship between $C$. fetus subsp. venerealis and $V$. fetus subsp. intestinalis concerning the specific structures of phage adsorption $(9,16)$; (iv) almost all strains of $C$. fetus subsp. venerealis and $V$. fetus subsp. intestinalis contain the same carbohydrates in 
TABLE 4. $G+C$ contents of DNA of 15 strains of Campylobacter species ${ }^{a}$

\begin{tabular}{|c|c|c|c|c|}
\hline \multirow[b]{2}{*}{ Strains identified $a s^{b}$} & \multirow[b]{2}{*}{ Ref. } & \multirow[b]{2}{*}{ Method } & \multicolumn{2}{|c|}{$\mathrm{G}+\mathrm{C}$ mean value $(\%)$} \\
\hline & & & Strains & $\operatorname{Taxa}^{c}$ \\
\hline $\begin{array}{l}\text { 1. C. fetus subsp. fetus } \\
\text { CIP } 5395 \\
\text { CIP } 5396 \\
\text { Ovine } 751 \\
\text { 2. C. fetus subsp. venerealis } \\
\text { CIP } 5443 \\
\text { CIP } 6829 \\
\text { CIP } 6829 \\
\text { Bovine R9 } \\
\text { 3. C. coli } \\
\text { Uccle } 1408 \\
\text { Human } 662 \\
\text { Avian } 1802 \text { GB } \\
\text { Avian } 1803 \mathrm{C} \\
\text { 4. C. jejuni } \\
\text { Uccle } 91 \\
\text { 5. C. sputorum subsp. bubulus } \\
\text { CIP } 5420 \\
\text { CIP } 5421 \\
\text { CIP } 5422 \\
\text { CIP } 53103\end{array}$ & $\begin{array}{r}47 \\
47 \\
2 \\
47 \\
c \\
e \\
2 \\
f \\
2 \\
2 \\
2 \\
f \\
f \\
47 \\
47 \\
47 \\
47\end{array}$ & $\begin{array}{l}\mathrm{C} \\
\mathrm{C} \\
\mathrm{T} \\
\mathrm{C} \\
\mathrm{C} \\
\mathrm{D} \\
\mathrm{T} \\
\mathrm{T} \\
\mathrm{T} \\
\mathrm{T} \\
\mathrm{T} \\
\mathrm{T} \\
\mathrm{T} \\
\mathrm{C} \\
\mathrm{C} \\
\mathrm{C} \\
\mathrm{C}\end{array}$ & $\begin{array}{l}35.4 \\
33.1 \\
34.7 \\
\\
34.4 \\
35.3 \\
35.7 \\
33.4 \\
33.1 \\
33.3 \\
32.1 \\
32.4 \\
31.5 \\
30.9 \\
29.7 \\
30.4 \\
29.5\end{array}$ & $\begin{aligned} \mathrm{GC}_{\mathrm{i}} & =34.4 \\
\mathrm{GC}_{\mathrm{v}} & =34.4\end{aligned}$ \\
\hline
\end{tabular}

${ }^{a}$ Abbreviations Ref., references; $\mathrm{C}$, chromatography; $\mathrm{T}$, melting temperature analysis; $\mathrm{D}$, buoyant density in $\mathrm{CsCl}$.

${ }^{b}$ For strains studied by Basden et al. (2), the identification was made on the basis of the published characters (especially growth in glycine, growth at $42 \mathrm{C}$, and $\mathrm{H}_{2} \mathrm{~S}$ production).

$c$ The four observed averages are significantly different $(P<0.001)$. The differences are significative between $\mathrm{GC}_{\mathrm{i}}$ and $\mathrm{GC}_{\mathrm{c}}(0.02<P<0.05)$ and between $\mathrm{GC}_{\mathrm{c}}$ and $\mathrm{GC}_{\mathrm{b}}(0.001<P<0.01)$.

${ }^{d}$ Personal, unpüblished results.

$e^{e}$ M. Mandel, personal communication.

$f$ A. Florent, personal communication.

their cell walls (51); and (v) probably all strains of $C$. fetus subsp. venerealis and some of the strains of $V$. fetus subsp. intestinalis belong to the same serotype, $0: 1(35)$ or $\mathrm{A}(3,38)$.

From the above it is clear that the previously described subspecies of $V$. fetus (synonym: $C$. fetus) do belong to the same species. One of these subspecies must be designated as the type subspecies of the species. The type subspecies is that which contains the type strain of the species. Since no type strain exists for $C$. fetus, a neotype strain must be designated, and the subspecies which contains the neotype becomes the type subspecies. In accordance with Rule 21 of the International Code of Nomenclature of Bacteria (12), the subspecific epithet in the name of the type subspecies must be the same as that for the species. Thus, whichever subspecies of $C$. fetus contains the neotype strain, the subspecific epithet in its name must be changed to fetus.

The choice of $V$. fetus subsp. intestinalis as the type subspecies seems better to us for the following reasons: (a) C. fetus was stated by the original observers of this microorganism $(34,53)$ to be the agent responsible for infectious abortion of cattle and sheep but not for enzootic venereal sterility in cattle; this latter disease was recognized later by Sjollema et al. (49), and its etiological agent was proposed as a new subspecies by Akkermans et al. (1). The first strains isolated by Smith (52) were recovered from fetuses and placentas of aborting cows, and thus the specific epithet "fetus" was used in the name of this bacterial species (53). At the present time, it is known that the $C$. fetus strains responsible for infectious abortion have the characteristics of $V$. fetus subsp. intestinalis.

(b) C. fetus subsp. venerealis is adapted to a very restricted ecological niche (genital tract of cattle) owing to its high degree of parasitism; its pathogenicity is unvaried. Therefore, it is possible to consider $C$. fetus subsp. venerealis as a "defective mutant" of $V$. fetus subsp. intestinalis. The latter subspecies can be considered a "wild type," more versatile with regard to its ecological niche and pathogenicity. Thus, 
it better represents the species from an evolutionary point of view.

Consequently, we designate strain CIP 5396 (= ATCC $27374=$ NCTC 10842), which has the characteristics of $V$. fetus subsp. intestinalis, as the neotype strain of Campylobacter fetus. This strain, described below, is also the neotype strain of the type subspecies of $C$. fetus.

Description of strain CIP 5396, the designated neotype strain for $C$. fetus and its type subspecies. Morphology. The cells are gram negative, curved, comma-like, slender rods, 0.3 to 0.4 by 1.5 to $2.5 \mu \mathrm{m}$ (see Fig. 1 and 2). They often occur in the shape of an "S" or in chains with three to five spirals. No spherical forms have been observed in young cultures. Capsules are not produced.

The comma forms are actively motile by means of a single, polar flagellum showing two to four undulations (see Fig. 3 and 4). The "S"-shaped and helicoidal forms usually possess a single flagellum at each pole.

$\mathbf{G}+\mathbf{C}$ content. The guanine + cytosine content of the DNA is $33.1 \mathrm{~mol} \%$ (Table 4).

Growth characteristics. After $24 \mathrm{~h}$ of incubation, the colonies on nutrient agar, blood agar, and thiol agar are small, being scarcely perceptible to the naked eye. After $48 \mathrm{~h}$ the colonies

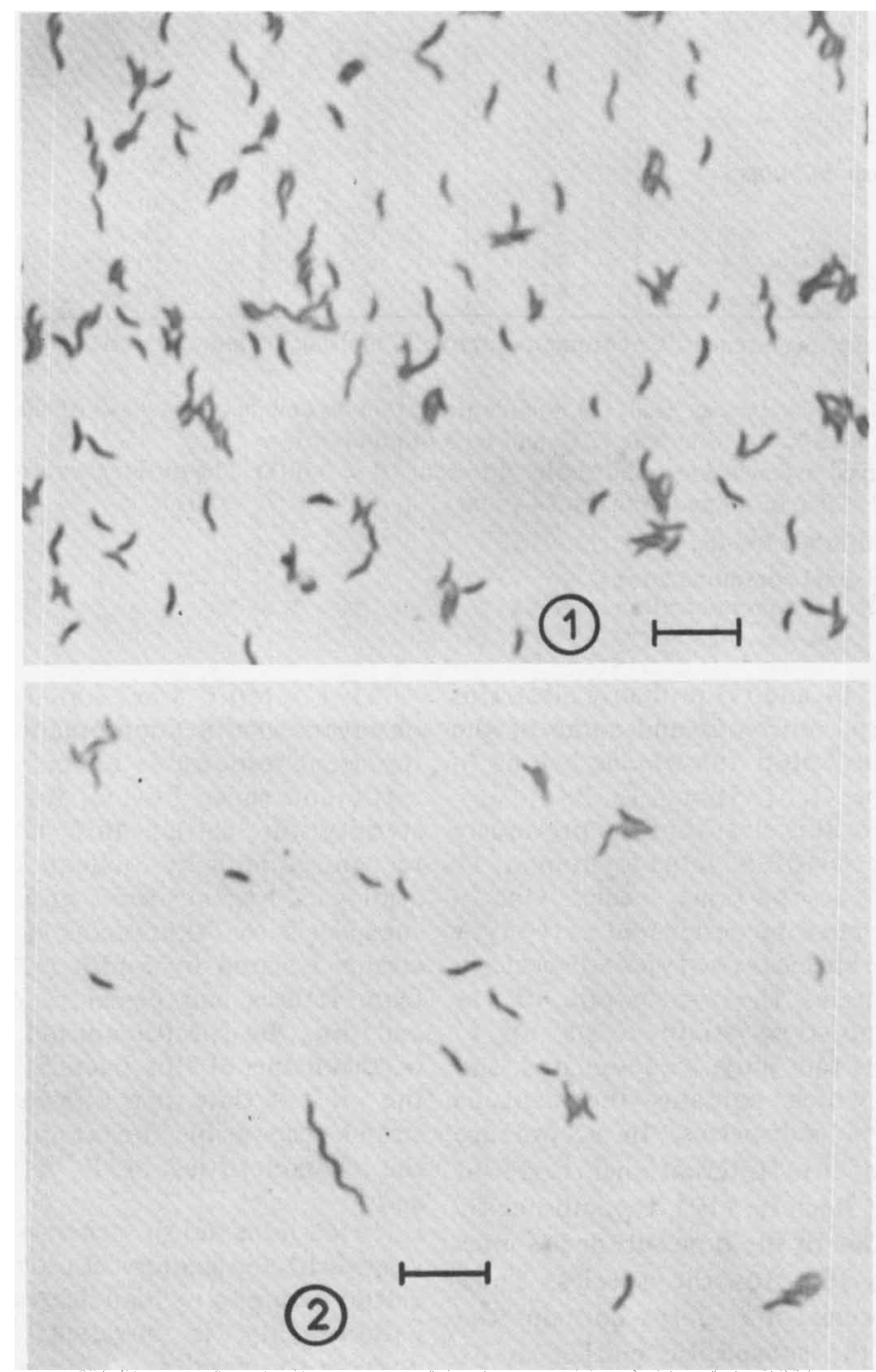

Fig. 1 and 2. Micrographs of gram-stained cells of C. fetus subsp. fetus CIP 5396. Magnification bars represent $5 \mu \mathrm{m}$. 

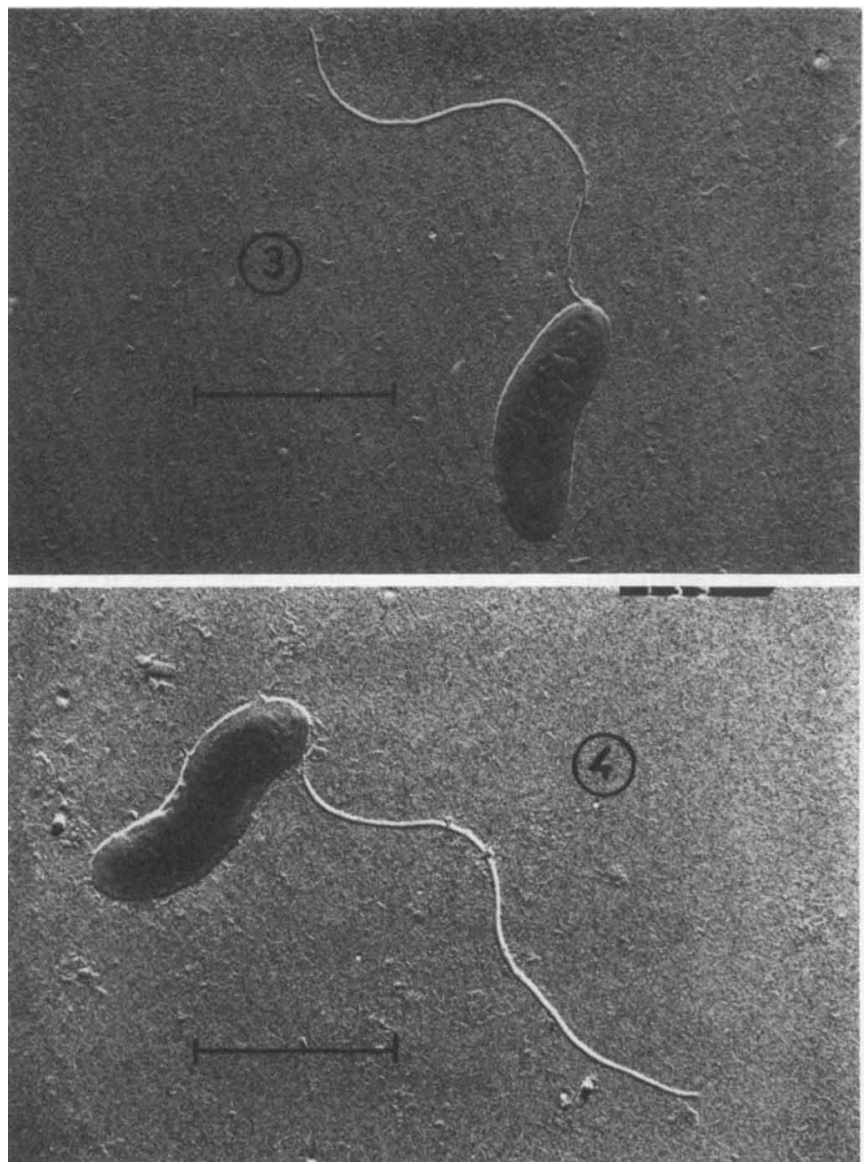

Fig. 3 and 4. Electron micrographs of C. fetus subsp. fetus CIP 5396 shadowed with palladium at an angle of 10 degrees. Scale marker, $1 \mathrm{\mu m}$.

attain a diameter of $1 \mathrm{~mm}$; they are round, raised, and translucent with a regular edge and a smooth, glistening surface.

In nutrient gelatin agar stabs, colonies extend throughout the medium, except in a surface zone of $2 \mathrm{~mm}$, after $48 \mathrm{~h}$ of incubation; at this time they have the aspect of bubbles centered on a point. On further incubation, colonies also develop in the surface zone.

In fluid Albimi broth, growth first occurs in a disk-shaped zone 2 to $3 \mathrm{~mm}$ beneath the surface and then after $48 \mathrm{~h}$ it becomes abundant in the upper portion of the medium.

The growth yields on solid media, calculated according to the method of Fletcher and Plastridge (17) and expressed in optical densities, are: nutrient agar, 0.37 ; blood agar, 0.50 ; thiol agar, 0.66; yeast extract agar, 0.40; and defined medium, 0.08 . Thus, this strain is not particularly exacting with respect to its nutritional requirements since the growth rate is good on all complex media used; however, its growth rate on the defined medium is weaker than that of the majority of strains studied by us and by Fletcher and Plastridge (17).

In an atmosphere of $5 \% \mathrm{O}_{2}, 10 \% \mathrm{CO}_{2}$, and $85 \% \mathrm{~N}_{2}$, growth is a little faster and more abundant than in an atmosphere of $90 \%$ air and $10 \% \mathrm{CO}_{2}$. In air, even with a heavy inoculum, only a few colonies grow after 3 or 4 days.

Good growth occurs at $25 \mathrm{C}$, but there is no growth at $42 \mathrm{C}$.

Biochemical properties. CIP 5396 is catalase positive, oxidase positive, and reduces nitrates to nitrates. In deep nutrient gelatin agar, anaerobic growth is not inhibited by chlorate; the nitrate reductase of this strain must therefore be of type B (41).

$\mathrm{H}_{2} \mathrm{~S}$ is not produced in fluid Albimi broth without cystine but is produced in fluid Albimi broth supplemented with $0.02 \%$ cystine- $\mathrm{HCl}$.

This strain does not produce acid from carbohydrates in Hugh and Leifson's medium, does not liquefy gelatin, does not grow on 
Simmons' citrate, and does not produce indole.

Tolerance. Good growth occurs in media containing $1 \%$ glycine, $10 \%$ ox bile, $8 \%$ glucose, $0.1 \%$ sodium selenite, $1 / 33,000$ Brilliant Green, or $40 \mu \mathrm{g}$ of nalidixic acid per ml. The growth on selenite produces a reduction of this compound.

There is no growth in media containing $3.5 \%$ $\mathrm{NaCl}$ or $1 \mathrm{mg}$ of TTC per ml. The strain is insensitive to vibriostatic compound 0/129.

Serological typing. The cells of this strain were agglutinated by $0: 2$ antiserum with a titer of 1/320 but not by $0: 1$ antiserum. Therefore, this strain belongs to serotype $\mathrm{O}: 2$ (or $\mathrm{B}$ ).

Because strain CIP 5396 has been designated herein as the neotype strain of Campylobacter fetus and because this strain belongs to $V$. fetus subsp. intestinalis, this subspecies is the type subspecies of the species. According to Rules 7 and 21 of the International Code of Nomenclature of Bacteria (12) and as pointed out earlier in this paper, the subspecific epithet in the name of the type subspecies must be the same as the specific epithet. Thus the correct name of the type subspecies of $C$. fetus is $C$. fetus subsp. fetus, of which $V$. fetus subsp. intestinalis Florent 1959 is an earlier, but illegitimate, objective synonym.

\section{ACKNOWLEDGMENTS}

We warmly thank P. Thibault, formerly Director of the laboratory of the Collection of the Pasteur Institute, for his aid in the study of the microaerophilic, vibrio-shaped bacteria and for allowing us to use some of his unpublished results. Thanks are also due to A. Florent, Director of the National Institute of Veterinary Research (Uccle-Bruxelles), who sent us strains of $C$. coli and $C$. jejuni and who permitted us to use his unpublished observations; to $W$. Winkenwerder, who sent us the reference serotype strains of C. fetus; to M. Mandel, who verified the $\mathrm{G}+\mathrm{C}$ content of the DNA of a C. fetus strain by the method of buoyant density; and to R. Y. Stanier, who so willingly revised the English translation of this manuscript.

\section{REPRINT REQUESTS}

Address requests for reprints to: Dr. M. Véron, Laboratoire de Bactériologie, Faculté de Médecine Necker, 156, rue de Vaugirard, 75730 Paris Cedex 15, France.

\section{LITERATURE CITED}

1. Akkermans, J. P. W., J. I. Terpstra, and H. G. Van Waveren. 1956. Over de betekenis van verschill- ende vibrionen voor de steriliteit van het rund. Tijdschr. Diergeneesk. 81:430-435.

2. Basden, E. H., M. E. Tourtellotte, W. N. Plastridge, and J. S. Tucker. 1968. Genetic relationship among bacteria classified as Vibrios. J. Bacteriol. 95:439-443.

3. Berg, R. L., J. W. Jutila, and B. D. Firehammer. 1971. A revised classification of Vibrio fetus. Amer. J. Vet. Res. 32:11-22.

4. Bøvre, K., and S. D. Henriksen. 1962. An approach to transformation studies in Moraxella. Acta Pathol. Microbiol. Scand. 56:223-228.

5. Bryans, J. T., and A. G. Smith. 1960. Physiological properties of pathogenic and nonpathogenic Vibrio species isolated from cattle, sheep and chickens. Cornell Vet. 50:331-338.

6. Bryner, J. H., and A. H. Frank. 1955. A preliminary report on the identification of Vibrio fetus. Amer. J. Vet. Res. 16:76-78.

7. Bryner, J. H., A. H. Frank, and P. A. O'Berry. 1962. Dissociation study of Vibrios from the bovine genital tract. Amer. J. Vet. Res. 23:32-41.

8. Bryner, J. H., P. A. O'Berry, and A. H. Frank. 1964. Vibrio infection of the digestive organs of cattle. Amer. J. Vet. Res. 25:1048-1050.

9. Bryner, J. H., A. E. Ritchie, J. W. Foley, and D. T. Berman. 1970. Isolation and characterization of a bacteriophage for Vibrio fetus. J. Virol. 6:94-99.

10. Davis, G. H. G., and R. W. A. Park. 1962. A taxonomic study of certain bacteria currently classified as Vibrio species. J. Gen. Microbiol. 27:101-119.

11. Doyle, L. P. 1948. The etiology of swine dysentery. Amer. J. Vet. Res. 9:50-51.

12. Editorial Board of the Judicial Commission of the International Committee on Nomenclature of Bacteria (ed). 1966. International code of nomenclature of bacteria. Int. J. Syst. Bacteriol. 16:459-490.

13. Elazhary, M. 1968. An assay of isolation and identification of some animal Vibrios and of elucidation of their pathological significance. Meded. Veeartsenijsch. Rijksuniv. Gent. 12(no 1-4):1-80.

14. Feeley, J. C. 1966. Minutes of IAMS Subcommittee on Taxonomy of Vibrios. Int. J. Syst. Bacteriol. 16:135-142.

15. Firehammer, B. D. 1965 . The isolation of Vibrios from ovine feces. Cornell Vet. 55:482-494.

16. Firehammer, B. D., and M. Border. 1968. Isolation of temperate bacteriophages from Vibrio fetus. Amer. J. Vet. Res. 29:2229-2235.

17. Fletcher, R. D., and W. N. Plastridge. 1963. Chemically defined medium for some microaerophilic Vibrios. J. Bacteriol. 85:992-995.

18. Florent, A. 1953. Isolement d'un Vibrion saprophyte du sperme du taureau et du vagin de la vache (Vibrio bubulus). C. R. Soc. Biol. 147:2066-2069.

19. Florent, A. 1956. Méthode d'isolement de Vibrio fetus à partir d'échantillons polymicrobiens, spécialement du liquide préputial. Milieu sélectif "coeur-sang-gélose au vert brillant" en microaéro- 
biose. C. R. Soc. Biol. 150:1059-1061.

20. Florent, A. 1959. Les deux vibrioses génitales: la vibriose due à $V$. fetus venerealis et la vibriose d'origine intestinale due à $V$. fetus intestinalis. Meded. Veeartsenijsch. Rijksuniv. Gent. 3(n०3): 1-60.

21. Florent, A. 1963. A propos des vibrions responsables de la vibriose génitale des bovins et des ovins. Bull. Off. Int. Epiz. 60:1063-1074.

22. Frazier, W. C. 1926. A method for the detection of changes in gelatin due to bacteria. J. Infect. Dis. 39:302-309.

23. Gamaléia, N. 1888. Vibrio metschnikovi (N.SP.) et ses rapports avec le microbe du choléra asiatique. Ann. Inst. Pasteur 2:482-488.

24. Hugh, R. 1964. The proposed conservation of the generic name Vibrio Pacini 1854 and designation of the neotype strain of Vibrio cholerae Pacini 1854. Int. Bull. Bacteriol. Nomen. Taxon. 14:87-101.

25. Hugh, R., and E. Leifson. 1953. The taxonomic significance of fermentative versus oxidative metabolism of carbohydrates by various gram-negative bacteria. J. Bacteriol. 66:24-26.

26. Jones, F. S., M. Orcutt, and R. B. Little. 1931. Vibrios (Vibrio jejuni N. SP.) associated with intestinal disorders of cows and calves. J. Exp. Med. 53:853-863.

27. Kiggins, E. M., and W. N. Plastridge. 1956. Effect of gaseous environment on growth and catalase content of Vibrio fetus cultures of bovine origin. J. Bacteriol. 72:397-400.

28. King, E. O. 1957. Human infections with Vibrio fetus and a closely related Vibrio. J. Infect. Dis. 101:119-128.

29. King, E. O. 1962. The laboratory recognition of Vibrio fetus and a closely related Vibrio isolated from cases of human vibriosis. Ann. N.Y. Acad. Sci. 98:700-711.

30. Kovacs, N. 1956. Identification of Pseudomonas pyocyanea by the oxidase reaction. Nature (London) 178:703

31. Kuzdas, C. D., and E. V. Morse. 1956. Physiological characteristics differentiating Vibrio fetus and other vibrios. Amer. J. Vet. Res. 17:331-336.

32. Lecce, J. G. 1958. Some biochemical characteristics of Vibrio fetus and other related Vibrios isolated from animals. J. Bacteriol. 76:312-316.

33. Loesche, W. J., R. J. Gibbons, and S. S. Socransky. 1965. Biochemical characteristics of Vibrio sputorum and relationship to Vibrio bubulus and Vibrio fetus. J. Bacteriol. 89:1109-1116

34. Mc Fadyean, J., and S. Stockman. 1913. G. Brit. Board of Agric. and Fish., Rept. Dept. Comm. Epiz. Abortion, London, p. 22, and Appendix part III.

35. Mitscherlich, E., and B. Liess. 1958. Die serologische Differenzierung von Vibrio fetus-Stämmen. Deut. Tieraerztl. Wochenschr. 65:2-5 and 36-39.

36. Mohanty, S. B., G. J. Plumer, and J. E. Faber. 1962. Biochemical and colonial characteristics of some bovine Vibrios. Amer. J. Vet. Res. 23:554-557.
37. Morgan, W. J. B. 1959. Studies on the antigenic structure of Vibrio fetus. J. Comp. Pathol. 69:125-140.

38. Olivier, H. R. 1963. Traité de Biologie Appliquée. Maloine Ed. Paris. t. II.

39. Park, R. W. A., I. B. Munro, D. R. Melrose, and D. L. Stewart. 1962. Observations on the ability of two biochemical types of Vibrio fetus to proliferate in the genital tract of cattle and their importance with respect to infertility. Brit. Vet. J. 118:411-420.

40. Peckham, M. C. 1958. Avian vibrionic hepatitis. Avian Dis. 2:348-358.

41. Pichinoty, F., and M. Piéchaud. 1968. Recherche des nitrate-réductases bactériennes $\mathrm{A}$ et $\mathrm{B}$ : méthodes. Ann. Inst. Pasteur 114:77-98.

42. Plastridge, W. N., L. F. Williams, and D. G. Trowbridge. 1964. Antibiotic sensitivity of physiologic groups of microaerophilic Vibrios. Amer. J. Vet. Res. 25:1295-1299.

43. Prévot, A. R. 1940. Etudes de systématique bactérienne. V. Classification des vibrions anaérobies. Ann. Inst. Pasteur 64:117-125.

44. Rhodes, M. E. 1958. The cytology of Pseudomonas spp. as revealed by a silver-plating staining method. J. Gen. Microbiol. 18:639-648.

45. Ritchie, A. E., R. F. Keeler, and J. H. Bryner. 1966. Anatomical features of Vibrio fetus: electron microscopic survey. J. Gen. Microbiol. 43:427-438.

46. Schneider, D. W., and E. V. Morse. 1955. The growth and viability of Vibrio fetus and related Vibrios in media containing ox bile. Cornell Vet. 45:84-89.

47. Sebald, M., and M. Véron. 1963. Teneur en bases de l'ADN et classification des vibrions. Ann. Inst. Pasteur 105: 897-910.

48. Shewan, J. M., W. Hodgkiss, and J. Liston. 1954. A method for the rapid differentiation of certain non-pathogenic, asporogenous bacilli. Nature (London) 173:208-209.

49. Sjollema, P., T. Stegenga, and J. Terpstra. 1949. Infectious sterility in cattle, caused by Vibrio foetus. Proc. $14^{\text {th }}$ Int. Vet. Cong. (London). 3:123-127.

50. Smibert, R. M. 1965. Vibrio fetus var. intestinalis isolated from fecal and intestinal contents of clinically normal sheep: biochemical and cultural characteristics of microaerophilic vibrios isolated from the intestinal contents of sheep. Amer. J. Vet. Res. 26:320-327.

51. Smibert, R. M. 1970. Cell wall composition in the classification of Vibrio fetus. Int. J. Syst. Bacteriol. 20:407-412.

52. Smith, T. 1918. Spirilla associated with disease of the fetal membranes in cattle (infectious abortion). J. Exp. Med. 28:701-719.

53. Smith, T., and M. S. Taylor. 1919. Some morphological and biological characters of the spirilla (Vibrio fetus, N. SP) associated with disease of the fetal membranes in cattle. J. Exp. Med. 30:299-311.

54. Véron, M. 1965. La position taxonomique des Vibrio et de certaines bactéries comparables. C. R. 


\section{VERON AND CHATELAIN}

Acad. Sci. Paris 261:5243-5246.

55. Véron, M. 1966. Taxonomie numérique des vibrions et de certaines bactéries comparables. II. Corrélation entre les similitudes phénétiques et la composition en bases de l'ADN. Ann. Inst. Pasteur 111:671-709.

56. Vinzent, R., and A. Alloy. 1952. Avortement
INT. J. SYST. BACTERIOL.

vibrionien de la brebis. Remarques sur la culture de Vibrio foetus. Rec. Méd. Vét. 128:541-543.

57. Wyatt, G. R. 1955. Separation of nucleic acid components by chromatography on filter paper, p. 243-265. In E. Chargaff and J. N. Davidson (ed), vol. 1. The nucleic acids. Academic Press Inc., New York. 